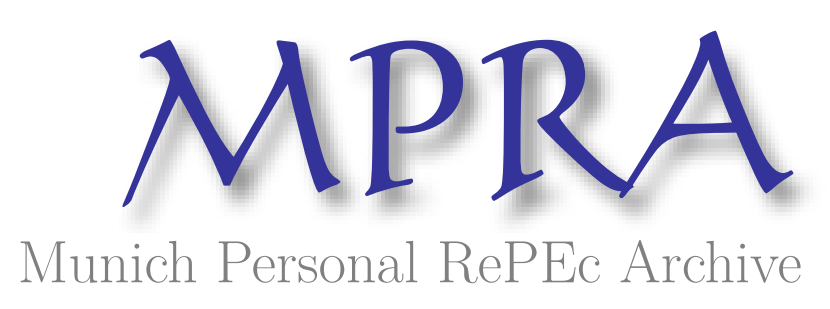

\title{
Economics of Technological Leapfrogging
}

Lee, Keun

UNIDO

2019

Online at https://mpra.ub.uni-muenchen.de/111034/

MPRA Paper No. 111034, posted 15 Dec 2021 00:27 UTC 
A Chapter for, The Challenges of Technology Upgrading and Economic Catch-Up in Emerging Economies. Jeong-Dong Lee, Keun Lee, Slavo Radosevic, Dirk Meissner, Nicholas S. Vonortas (eds). Oxford University Press, 2021.

An earlier version available as: UNIDO, DEPARTMENT OF POLICY, RESEARCH AND STATISTICS, WORKING PAPER 17/2019

\title{
Economics of Technological Leapfrogging
}

This revision; July 2020

\author{
Keun Lee
}

(Seoul national university)

*This is a short and revised version of the background paper prepared for the UNIDO IDR 2020 Report. 


\begin{abstract}
Latecomer economies are firms may be able to leapfrog older vintages of technology, and make pre-emptive investments in emerging technologies to catch up with advanced countries in new markets. Leapfrogging can be defined as latecomers trying something different a head of the forerunners, thereby leaping over them. The answer to the question whether the $4^{\text {th }}$ Industrial Revolution represents a new window of opportunity for leapfrogging or whether it constitutes a source of further risks for latecomers is that this depends entirely on the country's response and readiness, i.e. its industrial policy, digital literacy, the skill and education level, as well as domestic market size and position in the GVC. Policy recommendations for leapfrogging can also be made for different types of firms, such as incumbents and start-ups. The former comprises three types of firms, namely leaders, followers and laggards. Pathcreating type leapfrogging is more likely to take place in start-ups because they have invested the least in existing technologies or business models. Leader or follower type firms in emerging economies tend to have some experience with technology and absorptive capacity and are thus likely to be in a position to skip one or several stages, while managing the risks associated with leapfrogging. Lastly, laggard firms should not attempt pre-mature leapfrogging but should first build some absorptive capacity in their niche area and upgrade by moving up the higher end of the GVC.
\end{abstract}

Keywords: leapfrogging; window of opportunity; 4th industrial revolution; GVC; pathcreating; catch up; technological development. 


\section{Introduction}

One of the key issues in economic development by latecomers is whether they are to follow the same path of the forerunners or to create a new or different path of development (Lee and Lim 2001). Early literature (Lall 2000; Kim 1980; Westphal, Kim, and Dahlman 1985; Hobday 1995) has observed that the latecomer tends to achieve economic development by assimilating and adapting the forerunner's obsolete technology. This is consistent with product life cycle theory (Vernon 1966). However, an emerging view (Lee and Lim 2001; Lee 2013) points out that the latecomer does not simply follow the advanced countries' path of technological development but sometimes skip certain stages or even create their own path that is different from those of the forerunners. This observation is consistent with the idea of leapfrogging (Perez and Soete 1988) as it states that some latecomers may be able to leapfrog older vintages of technology, bypass heavy investments in previous technological systems or stages, and make preemptive investments in emerging technologies to catch up with advanced countries in new markets. Simply, leapfrogging can be defined as latecomers trying something different ahead of the forerunners, thereby leaping over them.

Several studies have confirmed leapfrogging or path-creating through case studies of catch-up in East Asia (Lee and Lim 2001; Lee et al. 2005; Mu and Lee 2005). Here, catch-up refers to a substantial closing of the market share gap between firms in a leading country and those in a latecomer or follower country. A recent article (Lee and Malerba 2017) and the companion articles published as a special issue in Research Policy also examined the cases of catch-up by the latecomers to see if they involved leapfrogging by the latecomers or not. ${ }^{1}$ Having observed that many industries have witnessed numerous changes in industrial leadership and in the successive catch-up by late entrants, they called this phenomenon as the catch-up cycles, in contrast to the product-life cycle (Vernon 1966) which involved only the changes in factory location but not the leadership.

A common finding from this literature is that successful cases of catching-up tend to involve variants of leapfrogging although they may start from imitating and learning from the incumbent at their early state of catch-up. Similarly, Joo et al (2016) analyze the data of patent citations of Huawei and Ericsson to see whether a latecomer (Huawei) catches up with the incumbent (Ericsson) by developing different (or similar) technologies compared with those by the forerunner (Ericsson). ${ }^{2}$ The results is that Huawei's patents tended to cite those by Ericsson initially but has eventually reduced such reliance and created a new path different from the incumbent. So, the catch-up paradox (Lee 2019) is that one cannot catch up (meaning overtake) if s/he continues to work on catching up (meaning imitation). In other words, eventual catchup and overtaking require latecomer economies to pursue a path that differs from that taken by its forerunners.

In his most recent book, Lee (2019) proposed a comprehensive theory of economic catchup, consisting of "late entry $\rightarrow$ three detours $\rightarrow$ leapfrogging," and positioned leapfrogging as the final stage of catching-up after the detour stage of building technological capabilities. The

\footnotetext{
${ }^{1}$ The special issue on catch-up cycles include cases of various sectors, such as that of cell phones, the memory-chip segment of semiconductors, cameras, steel, mid-sized jets, and wine.

${ }^{2}$ Similar technologies imply that the latecomer simply attempts to imitate the incumbents, whereas different technologies refer to the latecomer seeking to create new technologies and take a different technological path or trajectory from those of the incumbents.
} 
three detours, in terms of innovation, includes the following: the first detour is to promote minor innovations via petit patents rather than the high level of innovation via regular patents, the second detour is to increase the share of domestic value-added in exports rather than keep relying on GVCs, and the third or final detour is to pecialize in short cycle technologies rather than long cycle technologies. Taking detours are necessary because of the two failures (capability and size failures) in latecomer economies and one barrier of IPR protection in the north and small space for intervening policy under the WTO regime. In this theory, leapfrogging is necessary because the detours are not enough to raise the latecomers to the level of high income beyond the middle-income trap situation.

In other words, leapfrogging becomes necessary as a means of bypassing the IPR that forerunners hold by jumping ahead into new generations of technologies. Thus, leapfrogging is highly likely to succeed when executed during a shift in paradigm or generation or during exogenous moments of disruption, which early Schumpeterians, such as Perez and Soete (1988), coined as "windows of opportunity." Finding ways to overcome entry barriers is one of the key motivations for utilizing leapfrogging. A window of opportunity is a moment in time in which the entry barriers for latecomers recede. Meanwhile, Hidalgo et al.'s concept of product spaces and economic complexity does not consider entry barriers and related competition with the incumbent.

Latecomers tend to experience difficulties because of entry barriers existing in many product areas, and because they have to compete with the incumbents to be able to enter and occupy spaces. Thus, in our dynamics of economic catch-up, the role of leapfrogging is similar to "flying on a balloon when the conventional ladder used to catch-up is kicked away" (Lee 2019). As we can only fly balloons under favorable weather conditions, economic leapfrogging becomes successful only when exogenous windows of opportunity are available. Certain preconditions for flying also exist, such as having built-up capabilities meaning driving skills. Otherwise, we may fall to the ground instead of flying into sky.

This paper provides an updated review of the literature on leapfrogging. Specific topics to be covered include the followings. Section 2 discusses the origins and variations of the concept of leapfrogging. Section 3 discusses why the latecomer economies and firms need to try leapfrogging in terms of its benefits as a strategy for technological development. Section 4 discusses the pre-conditions to try leapfrogging and the associated risks of leapfrogging and how to manage the risks. Section 5 identifies the three windows of opportunity to try leapfrogging, such as emerging of new techno-economic paradigms, changes in demand conditions, and the institutional windows including asymmetric regulation and industrial policies.

Section 6 discusses how the leapfrogging can be an effective response by the latecomers in preparing for the $4^{\text {th }}$ industrial revolution (4IR hereafter) and to achieve the goals of sustainable development, and illustrates diverse cases of leapfrogging in latecomer economies. Finally, the last section, or section 7, discusses the issues of implementing the leapfrogging strategies under the heading of enabling conditions and policies for leapfrogging, and also discusses prospects of leapfrogging-based development. In the last two sections, discussion of policy issues related to leapfrogging will be based on the Schumpeterian conceptual framework, called the NIS (national innovation systems), which is about the relationship among the actors involved in creating, diffusing and utilizing knowledge and innovations, such as firms, public 
labs, government ministries, financial actors, IPRs systems and educational systems (Lundvall 1992). Effectiveness of each nation's NIS would determine innovative and economic performance of countries, and wrong response to new innovations is considered as a symptom of system failure which lead to mal-function of the systems.

\section{What is Leapfrogging: Origins and Variations}

The origins of the leapfrogging thesis may be regarded as going back to the idea of the so-called latecomers' advantage by Gerschenkron $(1962 ; 1963)$ that these countries may adopt and use the technology only after it become matured enough to have the standardized capital goods suitable for mass production. However, this discussion was confined to the catching up in the mature technology. It is Freeman and Soete (1997) and Perez and Soete (1988) that apply the idea with focus on the role of the new technological paradigm which brings forth a cluster of new industries. Their insight is that emerging technological paradigms serve as a window of opportunity for the latecomers, not being locked into the old technological system and thus being able to grab new opportunities in the emerging industries.

Perez and Soete (1988) discussed the latecomers' advantages for leapfrogging in terms of the following three aspects of entry barrier, accessibility of knowledge, and the possibility of lock-in by the incumbents. First, since the equipment to produce new industry goods are not developed yet, general-purpose machines should be utilised and production volume is small. Therefore, the entry barrier associated with economy scale does not exist. Second, in the initial stage of new technological paradigm, the performance of technology is not stable and not parochial to a firm. Therefore, if there are only the human resources who could access the sources of knowledge and create new additional knowledge, entry into emerging technology can be easier than during the later stage of technological evolution. Third, catching-up countries can be said to be in a rather advantageous position as they are not locked into old technologies whereas the advanced country tend to be locked into old technologies due to the sunk costs of their investment.

It was in Lee and Lim (2001) that the idea of leapfrogging was provided more flesh from the examples from the Korean industries and the concept was more clarified by the concepts of path-following, stage-skipping and path-creation by the latecomers in their technological development, in which path means the trajectory of technologies and stage means the stages in the trajectories. Lee and Lim observed that the strategies of path-creation and stage-skipping can be regarded as two variants of leapfrogging.

Following Lee and Ki (2017), these three strategies can be explained in Figure 1, which shows the different trends of the productivities (shown at the vertical axis) of technologies of different generations (with the horizontal axis representing time). Let us suppose that the current time is period 91 in Figure 1 and that the incumbent firms have adopted the currently most upto-date, second-generation technology, and are thus enjoying the highest productivity. Therefore, three choices or strategies are available for a latecomer firm that intends to make a late entry.

\section{[INSERT FIGURE 1 HERE]}

The first choice is to adopt the first-generation or oldest technology with the lowest price, that is, a path-following strategy, which indicates that latecomers move along the old technical 
trajectories of incumbents. An advantage of this strategy is that established firms care less about the transfer or leakage of proprietary technologies. Old technologies tend to be readily available at low prices, particularly during business downturns. However, given their low level of productivity, late-entrant firms cannot compete with the incumbent in the same market. Thus, these firms must try to enter a different segment (low-end segments).

The second choice is the stage-skipping strategy, which refers to the case in which latecomer firms follow the same path as that of incumbents but skip older-generation technology (Generation 1 in Figure 1) to adopt the most up-to-date technology (Generation 2 in Figure 1); this technology is of the same generation as the technology of incumbents. Thus, fierce competition may occur between incumbents and late entrants as the latter is to adopt upto-date technology. Aside from the matter of available financial resources to purchase up-todate technology, another issue is the market availability of such up-to-date technology or the willingness of an established firm to transfer such technology to latecomer firms (Lee and Ki 2017). In this context, IPR (intellectual property rights)-based protection of technologies may be a barrier for catch-up. Once this matter of technology transfer or acquisition is solved to the benefit of a late entrant, this firm may emerge as a powerful rival because the late-entrant firm not only enjoys the same productivity levels as the incumbent but also utilizes the probably low costs of labor.

The third choice is the path-creating strategy. This refers to the case of a latecomer exploring its own path of technological development by utilizing a new generation of technology. Figure 1 shows that, in this strategy, the late entrant chooses the emerging or thirdgeneration technology ahead of the incumbent. This strategy is consistent with the idea of leapfrogging discussed by Perez and Soete (1988). An apparent advantage of this path creating or leapfrogging is that this strategy is focused on technologies with high long-term potential or productivity as shown in Figure 1. However, a risk is that the emerging or new technology is neither stable nor reliable, and it has low productivity or high costs at its early stage as shown in Figure 1. Despite the high potential of this emerging technology, a firm that adopts the technology has to endure high costs. Thus, losses during the initial stage in the market might be incurred.

As explained in Lee and $\mathrm{Ki}$ (2017), the preceding idea is consistent with theory of Scurves (Foster 1986), which states that the inferiority of a new technology at its first appearance discourages incumbents from introducing the new generation of technology. In this sense, a new technology can be a source of the incumbent trap and a window of opportunity for latecomers that are free from the "replacement effect of new technology" (Arrow 1962). In other words, incumbent firms tend to ignore, by rational calculation or mistake, emerging technologies with potential, and these firms remain complacent with high productivity from current technologies. Although this choice may be rational in the short run, incumbent firms may lose out to other firms that take the risk of adopting emerging technologies and eventually attain higher productivity, thereby winning the market from incumbents.

Interestingly, not every firm, but probably late entrants or inferior firms with productivity levels that are lower than those of the leading firm, has many reasons to shift rapidly to new technologies. In this sense, latecomers have a greater incentive than incumbents to take the risk of adopting new technologies. However, even such risk taking by latecomers usually requires initial support from the government. Without subsidies or incentives, few latecomer firms 
would take the risk of adopting emerging technologies because they tend to face small or weak demand during the initial entry stage and thus would have a hard time achieving the initial production volume that would enable some degree of scale economy.

Thus far, technologies are treated as exogenous, and firms, especially latecomer firms, are treated as if they are facing the binary choice of adopting new technologies or not. However, latecomers usually not only assimilate the adopted technologies but also improve them substantially, an approach that is often called follow-on innovation, incremental innovations, or reinvention (Lee and $\mathrm{Ki}$ 2017). Rogers (2003) observed that reinvention occurs at the implementation stage for numerous innovations and for many adopters, and reinvention leads to an increased rate of adoption of an innovation. Following this line of thought, we can conceive of two types of path creation depending on whether a new path is created by in-house, endogenous innovation activities by the latecomers, or by adopting the exogenous or supplierdriven innovation earlier than the incumbents do and then further improving the adopted technologies. The former type may be common in product innovation or IT sectors, such as semiconductors, whereas the latter type may be relevant in process innovation-prone sectors, such as the steel industry, and can be termed the adoption and follow-on innovation mode. ${ }^{3}$

Another dimension of leapfrogging can be conceived in terms of inter-sectoral and intrasectoral leapfrogging depending upon whether it is happening with the same sector or across different sectors. The inter-sectoral leapfrogging is, to a certain extent, similar to "long jump" in Hidalgo et al (2007) which argues that latecomer economies must shift to core product spaces that are located far away from their current or periphery position. By contrast, intra-sectoral leapfrogging involves jumping across generations of technologies within the same sector. Intrasectoral leapfrogging is easier or less risky than the inter-sectoral long jump, as long as latecomers have already built certain absorptive capabilities, such as manufacturing experiences, in the given sectors.

The following Table 1 summarized the above discussion on the several variations of the concept of leapfrogging.

\section{[INSERT TABLE 1 HERE]}

\section{Why the Latecomers Need it: Two Reasons}

The two reasons for latecomers to try leapfrogging can be discussed in what follows. First of all, one theoretical point is the possible diminishing of the so-called catch-up effect as the latecomers get close to the frontier. At the earlier stage of development, many immediate benefits can be obtained by learning from and copying the practices of forerunning economies as suggested by Lin's theory of latent comparative advantages (Lin, 2012). However, these lowhanging fruits may be depleted, and some economies may need to reach high-hanging fruits with much effort or less marginal benefits. Eventually, an economy may need to grow its own fruits, and growing fruits that taste differently from those grown by others may be even better because in such a way, an economy does not have to compete directly with others.

\footnotetext{
3. This observation was suggested by Martin Bell as a comment to the paper of Lee and Ki (2017).
} 
The above point is related to the concept of the "catch-up paradox" introduced in a book by Lee (2019). This paradox states that "you cannot catch up if you just keep catching-up," where the former "catch up" means closing the gap between you and your targets, while the latter "catch up" means imitating your targets. This idea makes sense because if the latecomer keeps following the same path taken by his/her forerunners, then the latecomer cannot easily catch up or overtake them. In other words, the inferior cannot beat the superior if the former fights using the same weapon or strategies. In the old fable, David was able to beat Goliath by using a different weapon instead of engaging in physical contact. Another analogy can be made by referring to Xenon's paradox, which is also introduced in Lee (2019). This paradox explains how Achilles cannot overtake a turtle in a marathon by referring to the gradual exhaustion of the catch-up effect, which is observed as the latecomer gets closer to the target. Therefore, the latecomer must find an alternative path to free itself from the exhaustion of the catch-up effect.

The latecomer may also try taking a shortcut. However, this shortcut may become crowded when it becomes known to everybody, thereby jamming the latecomer in the road and preventing him/her from reaching the goal. This phenomenon is similar to the so-called adding up problem (Spence 2012; Lee and Ramanayake 2018), in which latecomer economies all try to export the same or similar products, thereby flooding the market and ending up with recordlow prices. As an alternative, these economies may take detours that may be longer yet less crowded than the main path, thereby allowing them to move fast if they have innovation capabilities.

The second reasons for latecomers to try leapfrogging has to do with the barrier of IPR protection by the incumbents against the possible imitation and imitative creation efforts by the latecomers (Lee 2019; ch 2). Under the auspices of the World Trade Organization (WTO), free trade has been promoted as a vehicle for world economic development. The WTO also regulates and provides guidelines for IPRs through the Trade-Related Aspects of Intellectual Property Rights (TRIPS) agreement, which represents the most extensive multilateral agreement toward the global harmonization of IPRs by setting out minimum standards for protection across member countries. One impact of TRIPS is that developing countries have increased their level of IPR protection to reduce the gap in the IPR protection level of developed and developing countries by 2005. The impacts of the expansion and enforcement of global IPRs contribute on export growth might be different because developed and developing countries correspond to different stages and mechanisms of economic development. Specifically, many exporting firms in the developing world tend to incur high costs when adapting to TRIPS obligations, and the strict enforcement of IPR laws in developed countries may curb the imports from developing countries because the latter's exports is negatively affected when they are too imitative in nature or are invented around existing products.

According to Shin et al. (2016), the US International Trade Commission (US ITC) has witnessed a fourfold increase in IPR-related disputes against foreign imports over the past two decades, and, interestingly, more US firms have complained against IPR violations than against unfair dumping, thereby highlighting the increasing importance of IPRs as a measure of trade protection. In fact, the entry of Korean firms into the US market has been marred by the patent disputes between US and Korean firms since the mid-1980s. One of the most noteworthy cases is the ban on Samsung's computer chip exports imposed by the US ITC for violating the patent 
rights of Texas Instruments. ${ }^{4}$ A leading high-tech firm from China, Huawei, also had a serious patent dispute with Cisco in 2011, thereby explaining the weak performance of Huawei's main product (telecommunication switches) in the US market.

Although Samsung and Huawei are big businesses with many resources to handle such disputes, solving these disputes can be a matter of life of death for SMEs as shown by the examples from Korea. ${ }^{5}$ If SMEs are entangled in IPR lawsuits, then the litigation usually hurts these firms in many ways and not only in terms of sales. Prohibitive patent license fees and marketing channels can be lost during the extended lawsuit period. Given these difficulties, most SMEs are highly concerned with patent lawsuits especially during the stage when they are starting to develop a new technology. In one survey, the Korean SMEs in the semiconductor equipment sector answered that while the localization of intermediate materials and goods is not difficult (which feasibility they estimated as "very high" (40.9\%) and "high" (59.1\%)), they regarded "IPR-related legal disputes" $(64.3 \%)$ as the biggest obstacle to localization. ${ }^{6}$

The implications of these incidents is that the possibly negative impact of the levels of IPR protection in the North may be greater for rapidly catching-up developing countries than for low-income countries with very low technological capabilities, weak export performance, or exports that are arranged by inter-firm trade in the form of contract manufacturing and FDIs. Such reasoning has been verified by the extensive econometric analysis in Shin et al. (2016), who found that as the IPR level of an importing country increases, the net marginal effect of technology on exports decreases, especially in the case of exports by those countries which technological levels are currently catching up. This finding implies that the strong IPR protection is the North acts as an obstacle to exporting from the South, which countries are currently catching up in terms of their level of technology. In this sense, IPR protection is identified as a source of MIT.

Given the situation that the IPR protection by incumbent economies and firms has acted as a barrier against the technological catch-up by the latecomers, one fundamental way to overcome this barrier is not to follow the same technological trajectory of the incumbent to avoid IPR disputes but to create a new path, take a detour, or try leapfrogging. In general, this means that the latecomer must make eventually a transition from imitation to innovation. In this regard, an interesting case can be that of Huawei, a leading IT company in China.

One study used patent citation data to investigate the catch-up of Huawei in China with Ericsson in Sweden, and found that Huawei relied on Ericsson as a knowledge source in its early days but subsequently reduced such reliance and increased its self-citation ratio to become more independent. ${ }^{7}$ The investigation of mutual citations (direct dependence), common citations (indirect reliance), and self-citations strongly indicate that Huawei has caught up with or overtaken Ericsson by taking a different path. Moreover, unlike Ericsson, Huawei developed its technologies by relying on recent technologies, which resulted in a patent folio with short citation lags (which means that its technologies have a short cycle). Huawei also relied heavily on scientific knowledge (so-called non-patent literature), which is a public good that is free

\footnotetext{
4. For details, see Lee and Kim (2010).

5. These SME cases are taken from Kim and Lee (2009).

6 . A survey conducted by the Center for Corporate Competitiveness of Seoul National University in 2004 (Kim and Lee 2009).

7. The study of this leading IT company from China is done in Joo et al. (2016).
} 
from IPR disputes with the incumbents. The citations to non-patent literature and the patent folio with short citation lags all imply that Huawei has extensively explored basic research and maintained up-to-date technologies to accomplish a technological catch-up, thereby avoiding another patent dispute with incumbent firms.

Overall, the examination of successful catch-ups (or overtaking cases) in East Asia suggests that exploring a technological path that differs from that taken by forerunners presents a possible and viable catch-up strategy for latecomers, and, in this sense, a "necessary" condition for overtaking. However, this strategy is not a sufficient condition as it involves a higher amount of risk (than going along a straight yet probably jammed road) and may end up in failure or accidents along the road. We turn to this issue of risks involved in leapfrogging in next section.

\section{One Pre-condition and the Two Risks of Leapfrogging}

\subsection{Pre-condition for Leapfrogging}

As discussed in Introduction, leapfrogging is like "flying on a balloon when the conventional ladder used to catch-up is kicked away," and then a certain precondition for flying does exist, that is having built-up technological capabilities. Without such capabilities, one may fall to the ground instead of flying into sky. However, it is not easy to build such capabilities which is quite different from production capabilities. Thus, although consolidating technological capabilities has long been suggested by many as a vital component of economic catch-up, guiding details for this process are lacking. Lee (2019) has thus suggested the three detours in building capabilities.

Latecomer economies must take detours because of the presence of two failures and one barrier: firm capability and size failures and IPR (intellectual property rights) protection from the incumbent North, respectively. Firm capability failure refers to the intrinsic difficulty of building innovation capabilities in developing countries. This type of failure radically differs from conventional market failure which states that $R \& D$ subsidies help achieve optimal (or increased) $R \& D$ amount. This view is valid only under the hidden assumption that firms are already capable of conducting R\&D. Otherwise, or under the lack of such capability, nothing will happen even with increased incentives or subsidies. A similar criticism applies to the notion that strong IPR protection leads to further innovation, which is true only under the assumption that the firm is already equipped with innovation capabilities. Size failure refers to the lack of world-class businesses in developing countries that are currently filled with SMEs, which are considered insufficient in leading a country toward a high-income status. The existence of these "two failures and one barrier" has necessitated latecomer economies to explore a new path or detour in building their innovation capabilities instead of replicating practices employed by advanced economies.

The first detour promotes imitative innovation under a loose IPR regime in the form of petit patents and trademarks instead of promoting and strengthening regular patent rights. The second detour focuses on global value chains (GVCs), specifically a non-linear sequence of the first increased, then reduced and increased GVC. In contrast to Baldwin (2016) who states that increased GVC participation is preferable, Lee (2019) and Lee, Szapiro and Mao (2018) warns against such a linear view. Instead, they suggest a GVC-related detour, in which an economy should initially learn by participating at the GVC but should later reduce its reliance on these 
chains at a certain point by building increased domestic value chains in sequential entries into high-end segments. Otherwise, the latecomers would remain at low value-added segments, which is an middle-income trap (MIT) symptom. The third detour means specializing first in short-cycle technology-based sectors and products (i.e., ITs) and, only at later stage, in longcycle sectors and segments (i.e., pharmaceuticals). Long-cycle technologies means that previous knowledge remains useful and important for a long period of time. Such technologies act as entry barriers against latecomers although they denote high profitability and thus, desirable attributes. Therefore, latecomers are advised to target short-cycle technologies, where entry barriers are low but growth prospect is good because of high innovation frequency that often disrupts the dominance of the incumbent.

In other words, the pre-condition for leapfrogging is to correct capability failure by providing latecomers with learning opportunities in order for them to enhance their innovation capabilities. Then, a starting point for a latecomer firm to build innovation capabilities is to establish its own in-house $R \& D$ center. Independent $R \& D$ efforts are required because foreign firms become increasingly reluctant to grant technology licenses to the rising latecomer firms, especially when the latter attempts to enter the higher value-added or profitability markets that are dominated by advanced countries. By establishing in-house R\&D laboratories, firms may explore diverse channels of learning and access foreign knowledge beyond simple licensing. Accessing foreign knowledge and trying new modes of learning are crucial because isolated inhouse $R \& D$ efforts are often insufficient in building indigenous R\&D capabilities. A diverse set of alternative modes of learning is available, including co-development contracts with foreign $R \& D$ specialist firms and/or with public R\&D institutes, mastering the existing literature, establishing overseas R\&D outposts, and initiating international mergers and acquisitions (M\&As). ${ }^{8}$ For example, since the early 1990s, a small number of Korean firms began to establish overseas R\&D posts to obtain easy and fast access to foreign technologies that cannot be easily acquired through licensing.

Only after building certain level of technological capabilities along the detours, the latecomer firms are getting ready to take the risk of trying leapfrogging.

\subsection{The Two Risks involved in Leapfrogging}

One early paper (Lee et al 2015) identified the following two risks involved in leapfrogging. The first kind of risk is that of choosing right technologies out of several possible emerging standards, and the second risk is how to create the initial market after the choice of technology to produce new goods.

In the early stage of technological paradigm, there tend to be available alternative technologies, among which one dominant or successful technology shall emerge eventually in the later stages. Therefore, if the catching up country invests in wrong technologies, the country shall fail in gaining returns from investments. Next, even after the catching up country becomes successful in choosing the right technology, it still needs to be successful in competition with other competitors from the advanced country. What follows discusses each of these two risks and how to manage the risk, using the example of the classical case of leapfrogging happened in TV industry of Korea (Lee et al 2005) and also in cell phone (Lee and Lim 2001).

\footnotetext{
${ }^{8}$ For details on these diverse learning modes, see Chapter 3 Section 2 of Lee (2019).
} 


\section{The Risk of Choice over Alternative Technologies}

When the Koreans decided to enter the high-definition (HD) TV technology, they faced tough choices regarding technology standards. Initially, they were heavily influenced by the Japanese leaders in analogue HD TV. The Japanese group arrived in Korea during the 1988 Seoul Olympic Games and staged a promotional tour of their achievement in the hope that the Koreans will follow them as in the past. Recognizing that HD TV would be a next-generation hot consumer item with immense technological and market potential, the Korean government established the Committee for Co-development of HD TV in 1989 with the participation 17 institutions comprising private firms, GRIs (government research institutes), and universities.

One year after Korea began the project, GI in the United States, a leading firm in digital TV technology, staged a historic demonstration of the possibility of digital TV in 1990. At the turn of this event, the Korean consortium decided to target digital HD TV instead of the Japanese developed analogue HD TV. However, the US standard was not yet determined at that time. In this regard, one interesting strategy by the Korean team was the decision to develop several alternative standards simultaneously, with different private companies in the team assigned to watch and follow different standards. This strategy can be called a 'parallel mover' in comparison with the first-mover strategy. Immediately after the so-called 'grand coalition' agreed to a common standard for digital TV, the Korean firms became a first mover in terms of launching their first digital TVs compatible with the common standard in the US markets.

In terms of access to foreign knowledge, Korean firms have been closely monitoring the technological activities of GI and other leading firms in the United States. As early as September 1989, Samsung first established an R\&D team for digital TV and a US branch (AML: Advanced Media Lab) in Princeton, New Jersey. In the case of LG, as early as 1990, it acquired a minor share of $15 \%$ of Zenith, a US company with a core technology in digital TV as early as 1990. LG eventually acquired $100 \%$ of equity of Zenith and was able to use the patented technology without fear of patent violation.

Another case of leapfrogging by the Korean consortium was cell phones, one of the most successful cases of a path-creating or leapfrogging event led by the private-public collaboration. When the Korean firms and the government authorities considered entry into this sector, the leader was the US firm Motorola, and the analogue system was dominant in the United States, whereas the TDMA-based GSM system was the dominant system in Europe. However, the Korean authorities (i.e., the Ministry of Information and Telecommunication) considered an emerging alternative of CDMA technology with higher efficiency in frequency utilization and higher quality and security in voice transmission. Thus, despite great uncertainty in the development of the world's first CDMA system as well as the strong reservations expressed by the telephone service provider and private manufacturers (e.g., Samsung and LG), the Ministry and the Electronics and Telecommunication Research Institute (ETRI) decided to support the CDMA. One of the main reasons for the decision is the consideration that if Korea merely followed the already established standards, the gap between Korea and its forerunners would never be reduced and thus catching up would take even longer. Thus, Korea chose a shorter but riskier path. 
The Korean government first designated the CDMA system development as a national R\&D project as early as 1989 . In 1991, the contract to introduce the core technology from and to develop the system together with the US-based Qualcomm was forged. In 1993, the Ministry declared CDMA to be the national standard in telecommunication. Given the high frequency of innovation and the high fluidity of trajectory, the telecommunication industry does not provide the latecomers any incentives for R\&D effort. Expected profits and other related gains from first-mover advantages served as a strong attraction, and the high risks were shared by the government-led R\&D consortium and knowledge alliance with Qualcomm. The ETRI also contributed to reducing technological uncertainty by providing accurate and up-to-date information on technology trends and by identifying the correct $R \& D$ targets that are more promising than alternatives.

\section{The Risk of Finding the Initial Market}

In mitigating the second risk of the existence of initial markets or not, we may first emphasize the importance of standard which is a critical factor in the market success of the new innovations, in particular digital technology. When the involved products are in the area of information or other emerging technology, an isolated development without paying attention to the issue of standards might lead to a failure of the whole project. In standard setting, collaboration and getting partnership with rivals or suppliers of complementary products are important. Also important is who create and get to the market first as the size of the market determines the success or failure of one standard against other. Again, in this competition for standard setting and market creation, the role of the governmental can be noted as it can plays the role of facilitating the adoption of specific standards and thereby influencing the formation of markets at the right times.

\section{Implications: Public-Private R\&D Consortium and the Incumbent Trap}

The above cases of digital TV and mobile phones in Korea demonstrate how the emerging new technological paradigm can serve as a window of opportunity for the catching-up firms. ${ }^{9}$ Actually, a long list of success with the public-private R\&D consortium, from digital telephone switches to memory chips (D-RAM), wireless phones (CDMA), and finally digital TV in Korea, confirms the positive role of the government and the GRIs in technological catch up by the latecomer firms. The private firms that participated in the public-private consortium all acknowledged the important function of the government in providing legitimacy to the large projects that are often difficult for private firms to support. The consortium also served as a field to pool together the domestic resources from various sources, especially resources in the universities. The contribution of public research laboratories is also critical in conducting the role of 'technology watch' to interpret and monitor the state-of-the art trend of R\&D activities in foreign countries.

In the meantime, the reasons why the Japanese digital TV producers became laggard toward Korean digital TV producers can be discussed in terms of the concept of the incumbent's trap. Japan was locked into 'analogue' HD TV since the 1980s as it created the first HD TV system in the 1980s. Although the Japanese government attempted to shift to digital TV in 1994, the effort was stifled by the firms that invested greatly in analogue HD TV. This early start and

\footnotetext{
${ }^{9}$ These implications are also explained in Lee et al (2005).
} 
lock-in by the Japanese firms signify the disadvantages and risk of being the technological pioneer, which is close to the so-called innovator's dilemma proposed by Christensen (1997). Japan was the forerunner in taking initiatives toward HD TV, but it was along the trajectory of analogue technology. However, Japan's merits turned into debt as the United States and other countries accepted the digital TV as the standard, and the latecomers decided to follow this trajectory. In this sense, this case eloquently demonstrates that shift of technological paradigm can penalize the leader while serving as a window of opportunity for latecomers who command complementary assets for using a new technological opportunity.

\section{Three Windows of Opportunity for Leapfrogging}

The preceding sections observed that leapfrogging involves latecomers accomplishing something ahead of the forerunners, thereby leaping over them. Thus, leapfrogging is highly likely to succeed when executed during a shift in paradigm or generation or during exogenous moments of disruption, which early Schumpeterians, such as Perez and Soete (1988), coined as "windows of opportunity." A window of opportunity is a moment in time in which the entry barriers for latecomers recede. Latecomers tend to experience difficulties because of entry barriers existing in many product areas, and because they have to compete with the incumbents to be able to enter and occupy spaces. Thus, in our dynamics of economic catch-up, the role of leapfrogging is similar to "flying on a balloon when the conventional ladder used to catch-up is kicked away." As we can only fly balloons under favorable weather conditions, economic leapfrogging becomes successful only when exogenous windows of opportunity are available.

The concept of leapfrogging has been also utilized in the theoretical framework called "catch-up cycles" developed by Lee and Malerba (2017), which pertain to successive changes in industrial leadership. Many industries have witnessed numerous changes in industrial leadership and in the successive catch-up by late entrants. The incumbent often fails to maintain its superiority in production or market shares, and a latecomer catches up with the incumbent. The latecomer who gains leadership then loses to another latecomer. In addition to the lead article by Lee and Malerba (2017), attempts to explain these phenomena are sectoral studies collected in a special issue on catch-up cycles published in Research Policy, which include cases of various sectors, such as that of cell phones, the memory-chip segment of semiconductors, cameras, steel, mid-sized jets, and wine.

The framework of catch-up cycles originated from the belief that product life cycle theory of Vernon (1966) cannot explain the phenomenon because the theory merely focuses on the location change of factories from advanced to developing countries, and leadership is assumed to remain with firms from advanced countries. The catch-up cycle concept is based on Schumpeterian notions of innovation systems applied at the sector level and on the evolution of these systems over time. ${ }^{10}$ Several discontinuities may occur during such an evolution of systems. These discontinuities are called windows of opportunity, which refer to the role of the rise of new techno-economic paradigms in generating leapfrogging. These windows of opportunity can be extended to additional dimensions corresponding to the building blocks of

${ }^{10}$ For the concept of the national systems of innovation, see Freeman (1987), Lundvall (1992), Nelson (1993), and for the SSI, see Malerba $(2002,2004)$ and Malerba (2005). 
a sectoral system, such as changes in demand conditions or in regulation and policies by the government.

Three window types can be opened for late entrants. One is the rise of a new technoeconomic paradigm that tends to threaten the advantage of existing first movers or incumbents involved in investment in the existing capital vantage. When a new paradigm arrives, latecomers and incumbents stand by the same starting line with the new technology. However, incumbent may fall behind by grasping on to old technology, with which they hold a dominant position. The propensity for incumbents to remain with the old paradigm for a prolonged time can be considered rational as they considerably invested in it. Thus, incumbents want to fully recover their investment costs. Depending upon the situation, instead of the full scale technoeconomic paradigm shift, a mini-paradigm, a new generation of technologies, or a new trajectory, can be a such window.

The second window of opportunity type is derived from the secondary components of SSI (i.e., demand conditions or market regimes), that is, a business cycle and/or abrupt change in market demand, including the rise of new consumers. Mathews (2005) indicated that business cycles create opportunities for challengers to rouse the industry as downturns play a cleansing role. Thus, weak players are forced into bankruptcy, and resources are released at low prices to be acquired by challenger firms aiming to enter the industry. These demand changes can be exogenous or intrinsic to the sector but exogenous to firms (e.g., the short-term cyclical behavior of prices of IT sector memory chips and panels).

The third window of opportunity can be opened by the government. This opportunity usually generates an asymmetric environment for incumbents and entrants through a range of regulations and supportive actions for entrants. Latecomers can utilize such asymmetries to offset initial cost differences associated with late entry.

Although the three types of windows of opportunity are assumed to be events that are often exogenous to latecomer firms, the firms should recognize and take advantage of these open windows to realize their potential. In other words, together with the notion of windows of opportunity, the catch-up cycle framework also uses the concept of "responses" by firms and systems at sectoral or national levels. A few firms from emerging countries and the sectoral system supporting them may respond to the opening of windows and then successful catch-up or rise in local or global markets. Current leaders from a certain country may fall behind due to a lack of effectiveness in firm and sectoral system response, such as in "incumbent trap" behavior, leading to misalignments with the new window. The gist of our theory is that diverse combinations of windows of opportunity and the responses of firms and sectoral systems of latecomers and incumbents determine the pattern of successive catch-ups that most likely emerge in a sector.

\section{Two Industry Cases}

It is also interesting to see that one or more windows come into play in a single sector over evolution of sectors. Here some example stories of some sectors are in order, starting from a case of steel industry. The steel industry has experienced two leadership changes (Lee and Ki, 2017). The first change was from the US to Japan in the late 1970s and early 1980s, and the second was from Nippon Steel in Japan to POSCO in South Korea during the late 1990s.

In this steel sector, the leadership shift from the US to Japan involved the technological 
and institutional windows but not the demand window. Japanese firms immediately adopted the Austrian innovation of the basic oxygen furnace method (BOF) that they further improved through follow-on innovation (Yonekura, 1994). The Japanese government was also involved because it arranged the collective licensing of BOF for significantly reduced royalty fees (Nakamura and Ohashi, 2012). In contrast, the US firms fell into an incumbent trap of remaining with existing methods (OHF).

Then, in the rise of the Korean steel company, called POSCO, the downturns in the global steel industry provided windows of opportunity for this latecomer. POSCO first initiated gradual catch-up from the low-end segment, adopting a path-following strategy of importing mature technologies from Japan, and then switched to the stage-skipping strategy for forging ahead by adopting up-to-date technology and capitalizing on downturns. The demand window in this case was significant because POSCO purchased state-of-the-art technologies at considerably low costs as a result of the global recession in the 1980s (D'Costa, 1999). The institutional window was also present for POSCO because the government participated in indicative planning for the growth of steel-consuming sectors, such as shipbuilding and automobile sectors. Eventually, POSCO, outperformed its "teacher" firm, Nippon Steel, in Japan in the late 1990s.

The POSCO case indicates that not upturn but downturn in business cycle can be a window of opportunity that allowed the latecomers to purchase and install state-of-the-art technologies at lower costs because of the downturn. The role of downturns was also noted in semi-conductors in the study of Shin (2017), which indicated that the Japanese firms (in the 1980s as late entrants to the US firms) and then the Korean firms (in the 1990s as late entrants to the Japanese firms) conducted aggressive investment during the downturns, while the incumbent firms were more cautious in their investment.

It is also worthwhile to look at the case of cell phone sector. Giachetti and Marchi (2017) found that leadership change in the cell phone sector occurred twice, with an interval of 14 years. The first change was in 1998 when Nokia and its digital cell phones dethroned Motorola, which invented analog cell phones. The second leadership change occurred in 2012, during the transition from regular cell phones to smartphones, when Samsung, together with Apple, dethroned Nokia in market shares.

In the cell phone sector, technological change was the most significant window of opportunity in both leadership change incidents. The emergence of digital technology was the window of opportunity in the transition from Motorola to Nokia, and the change from regular phones to smartphones was the significant window of opportunity in the transition from Nokia to Samsung. Unlike previous mobile operating systems, such as the Symbian of Nokia, the Android OS of Google was custom-built to support the touch interface that gained popularity among consumers. The first mobile phone vendor that incorporated the Android OS was Samsung. The demand window was significant in the first leadership change as individual phone users increased instead of business users, and the institutional window associated with the exclusive support of EU for digital GSM standards compared with the support of the US for multiple standards. In the transition from Nokia to Samsung, the role of the demand or institutional window was unclear during the forging-ahead stage in 2000, whereas the entry and gradual catch-up of Samsung in the $2 \mathrm{G}$ era in the 1990s were facilitated by regulatory intervention by the Korean government that established the code division multiple access 
(CDMA) as exclusive standard in Korean market. ${ }^{11}$

In general, the stories of catch-up in several sectors (Lee 2019; Ch. 5) suggest that although the path-following strategy based on initial factor-cost advantages may permit the gradual catch-up of the late entrants' market shares, a sharp rise of the latecomers' market shares is more likely to occur with a shift in technologies or demand conditions (particularly downturns). These shifts are facilitated by variants of leapfrogging, either the path creation or stage skipping by latecomers. Decisive investment on the opening of new windows irreversibly changes the leadership of the industry, namely, a forging ahead, which pushes the old incumbent towards the cliff of falling behind. Windows are always likely to open because generations of technologies and business cycles change frequently. Therefore, leadership change and catch-up by latecomers can be predicted to occur repeatedly. The decline of leadership can be predicted not only from the rise of latecomers but also from the "falling into trap" behavior of the incumbent. That is, leaders tend to be complacent with the current success and pay less attention to the emerging technological or market paradigm, including new types of consumers.

\section{Leapfrogging for the $4^{\text {th }}$ Industrial Revolution and Sustainable Development.}

\subsection{Leapfrogging for the Forth Industrial Revolution}

With the arrival of the $4^{\text {th }}$ Industrial Revolution (4IR) noted by the Schwab (2016) at the 2016 World Economic Forum, the question and challenge today, is whether the next generation of latecomer economies can also use manufacturing as a path to prosperity. The 4IR refers to the new waves of innovations consisting of several technologies comprising 3D-printing, IoT (Internet of things), AI (artificial intelligence), Smart car, big data, and on-demand economy (sharing economy), but could include smart health, renewable energies, and VR (virtual reality) technologies which are not much mentioned in his book.

Thus, it can be said that the existing mode of economic catch-up faces many challenges with the arrival of the 4IR in several aspects (Lee et al 2019). First, the Fourth Industrial Revolution is re-writing the rules of manufacturing. As the cost of automation plummets, lowcost labor is a less effective strategy to attract manufacturing investment. Second, with the 4IR, we see possibly the beginning of a trend towards re-shoring of manufacturing back to the rich world (eg, Apple in the US and Adidas making shoes in Germany). Third, some expect global supply chains would become flatter, and more regional and even national in order to reduce delivery times and to make manufacturing more responsive to local tastes and local demand conditions. This potentially reduces the level of economies of scale required for the producing for the whole world.

The ride and response of latecomer economies to these challenges would determine their eventual economic fortune. Those capable in performing new innovations would take advantage of the 4IR a new window of opportunity (Perez and Soete 1988) while those who are unable would see it as window of falling behind (destruction) and be stuck in the low income or middle-income trap (Lee 2013). In Schumpeterian economics, this 4IR can also be considered as an arrival of the new techno-economic paradigm, and thus could also be a window

11 See Lee and Lim (2001). 
of opportunity for latecomers to leapfrog. At the moment, most of 4IR technologies tend to be initiated not by latecomers but by the advanced economies, and also the response by the latecomer economies have been perceived as slow or in smaller scale (ILO 2016a). To the extent that this is true, the 4IR seems to be a counter-attack by the incumbent countries against the recent catch-by the latecomers, in particular against those in east Asia. In other words, the incumbent and latecomers do not stand at the same start line but the former has already departed from the line, leaving the latter behind again.

Despite the above conjecture, it still seems necessary to explore the possibility of the 4IR becoming a window for the latecomer economies and how they should do prepare for the 4IR revolution so as not to be stuck in the development trap. In general, we do not think it is already too late but there is still left a time to respond and take strategic actions. Ideally, while the 3IR was a window of opportunity for the first tier Asian economies, there is a possibility that 4IR can be so for the next tier latecomer economies.

Another dimension of the window of opportunity implied by the 4IR can be discussed in terms of startups and young SMEs versus incumbent firms in emerging economies. In other words, the 4IR can be a new window of opportunity more for startups and young SMES than incumbent firms in emerging economies in the sense that the latter firms are more like to be locked in, or be complacent with, existing technologies or business models or to take the inertiatype behavior and lukewarm attitude toward new technologies. In contrast, new firms have no or less sunk investment in old or exiting mode of technologies and business models and thus more inclined to try, or switch to, new technologies and business models.

Now, given that the scope of the 4IR is very broad and many of the related technological revolution are not much happening in developing countries, one may take a flexible definition of the 4IR. In this context, the concept of industry 3.0 (automation) and industry 4.0 (smart factory) would be more relevant for countries with some manufacturing basis. As a matter of fact, typical factories in developing countries are at the stage of industry 2.0 or mass-production stage, and thus even the automation (industry 3.0) is not much progressed, not alone transformation into a Smart Factory or industry 4.0 (ILO, 2016a: 4 and ILO, 2016b: 3). In general, the 4IR is expected to expedite the transition from mass-production (industry 2.0) to automation or leapfrogging into the Smart Factory system (industry 4.0).

Even if one takes the option of leapfrogging, it should be carefully managed because it comes together with both potentials and risks (Lee et al 2005). As discussed in the preceding section, the primary risk has to do with the choice of right technologies or standards. For instance, regarding 5G, we are seeing emergence of multiple standards. While Korean and US companies are about to launch the world-first 5G services and the associated cell phones, there exist differences in specifications of the standards. While Korean firms, like Samsung and LG, are preparing to produce the full scale 5G-compatible phones, the Verizon and Motorola team may launch LTE phones that may insert 5G module chips. In contrast, the Chinese firm, like Huawei, is reported to opt for a different standard, called 5G Advanced, which is supposed to be further improved version of the $5 \mathrm{G}$ products first released in 2019. Possibility of diverse $5 \mathrm{G}$ standards might affect choices by firms which plan to launch new products or services associated with $5 \mathrm{G}$, such as health-related wearables, autonomous driving solutions and products, drones and other IoT based products and services in smart factory systems.

In the meantime, an ILO study also illustrates both the opportunity and threat side of 
robotic automation. An ILO study of the sector finds that robot-based automation is basically "human centric," occurring in the form of collaborative robots, or "cobots", able to perform repetitive, high precision and difficult tasks, and thus this automation aids workers rather than replaces them (ILO 2016a: 32 and xx). Thus, the report by ILO determined that people still exceed the capabilities of robots in overall assembly, perception, flexibility, dexterity and adaptation to new duties, which means human workers are (for now) more cost-effective. However, the threat side is also there because compounded with predicted uptakes in $3 \mathrm{D}$ printing, displacement of lower skilled packaging and assembling jobs is possible.

\subsection{Leapfrogging for Sustainable Development}

Another impetus for leapfrogging can be discussed in terms of the global consensus toward sustainable development for which leapfrogging can serve as an effective way to switch to an environment-friendly, sustainable, mode of development (Lee 2019; Ch. 7). Figure 3 below shows the so-called, Environmental Kuznets Curve, where the degree of environmental damage is measured along the vertical axis and with per capita income on the horizontal axis. The idea of this curve is that an increasing environmental damage is expected with the initial rise of per capita income. Environmental damage may be mitigated after a certain point of growth of the income levels. Given this path of the forerunning economies, if all current latecomer economies continue to follow the path of the existing economic model of growth, the global goal to reduce carbon emission would be impossible and with substantial damage to the global environment. A better alternative is to skip a middle point, such as Point $\mathrm{C}$, by jumping or leapfrogging to Point D from B. With proper composition of economic activities and the use of better technologies, such leapfrogging becomes a possibility. ${ }^{\mathbf{1 2}}$

\section{[INSERT FIGURE 2 HERE]}

If the advanced countries see their path blocked by "carbon lock-in" (excessive dependence on fossil fuel systems), then latecomer countries can bypass such blockages by leapfrogging to cleaner and greener technologies. Mathews (2017; 2018) calls this alternative, "green development," based on the green industrial system free from fossil fuels and extensive resource throughput. Actually, a green window of opportunity has been opened up with the rise of various renewable energy technologies enabling the production of solar panels, wind turbines, new smart grid devices, electric vehicles, recharging stations, and others.

Thus, considering this green window of opportunity, late latecomers (those economies other than several East Asian economies who are already achieving significant catch-up) are in an appropriate position to attempt leapfrogging into an environment-friendly trajectory of development. Certainly, such leapfrogging requires the pre-existence or building up of a certain level of capabilities.

In what follows, we discuss several examples of leapfrogging in latecomer economies to explore the possibility of leapfrogging as the key latecomer development strategies for the $21^{\text {st }}$ Century.

12 This remark was also made in Lee and Mathews $(2013 ; 2018)$. 


\subsection{Cases of Leapfrogging in Latecomer Economies}

In a certain context and under certain conditions, such as the availability of foreign assistance, access to knowledge and/or funding, latecomers may attempt to leapfrog into newly emerging sectors, such as renewable energy or broad spectrum of technologies associated with the 4IR. In what follows, we discuss diverse cases of leapfrogging in latecomer economies.

\section{Two Cases from China}

Solar thermal technology is one of alternative sources of energy in the search for low carbon energy solutions. However, its diffusion has been slow or not effective. In contrast, China is making a notable success, especially in rural areas rather than in urban areas (Zhou et al. 2012). ${ }^{13}$ Solar thermal technology in China was developed early, in the 1980s, as a result of the R\&D project executed by the Tsinghua University as a part of China's national R\&D initiatives. After the University disclosed the vacuum tube patent so that the technology may be easily transferred to manufacturing sector, its production has increased to large scale. Now an interesting story in this market expansion is that it did not succeed in urban area due to the mismatch with the existing urban architecture but succeeded in rural areas. In other words, compared to gas and electric thermal system which are already installed in cities, solar thermal systems which function for only six months cannot be attractive to urban dweller. In contrast, solar thermal systems in the rural market can be successful because rural buildings tend to be of more simple structure which could been rebuilt by individual owners who care more about the practical utility and less about appearance. Most importantly, compared to no hot water at all, six months of hot water supply is a big attraction for rural users.

This case of solar thermal energy in China indicates that rural area bypassed the stage of gas or electricity-based heating but leapfrogged into the stage of solar thermal based heating. It also indicates that not only supply-side (technology) but also relative match or mismatch with the demand side factor can be a source of a leapfrogging. Solar water heater meant a huge disruption on the existing life and residence style of high-end or urban dwellers, whereas underdeveloped areas had no such high degree of lock-in which allowed them more receptive attitudes to alternative energy systems.

A case involving directly 4IR technologies can also be introduced, which may be considered a broadly-defined leapfrogging, such as Deep Glint which is one of the leading intelligent IoT technology company located in Beijing, China. It was founded by Zhao Yong in April 2013, who used to be a senior researcher at Google's research institute and one of the core members in R\&D team for Google Glass. ${ }^{14}$ It was started as a hi-tech camera and advanced security system company which uses computer vision to help monitor crowds. Currently this company utilizes advanced AI (artificial intelligence) technology to create products and services at low cost and can be deployed in a large scale. In 2018, DeepGLint was in the top 30 Chinese artificial intelligence (quasi) unicorn list and the top 100 Most Emerging Growth Enterprises list. It is a very technology-intensive company, with an increasing number of patents; by the end of 2018, Deep Glint has obtained 13 invention patents, 5 utility model patents, 3 design patents, and 10 software copyrights.

13 This case is originally from Lee and Mathews (2013; 2018).

14. The basic information about this company is from the company website, http://www.deepglint.com/aboutus. 
Given its original strength in face recognition technologies, its area for future growth seems to be autonomous driving which require AI-based technology to monitor a large number of moving objects and that seems to be why this company received equity investment from Hyundai Motor Company from Korea. So far, it has gone through the first two stages (A and B) of venture-capital funding with each stage's amount of investment of more than 18 million Chinese Yuan. ${ }^{15}$ Before it got investment from market, this company was also supported by several Chinse government program, such as the Torch Program and the Start Entrepreneur Program, which targeted, among others, the AI industry.

\section{Using IoT technologies for Fish Farming in Indonesia.}

Founded in 2013, eFishery is one of the first "fishtech" startups in Indonesia. It provides an Internet of Things (IoT) solution for fish and shrimp farming businesses. According to eFishery, feeding cost accounts for around $80 \%$ of total fish farming expense but feeding is done inefficiently by unskilled labor with no control or supervision. ${ }^{16}$ Thus, this company created a device that enables automated feeding of stock in fish farms; which results in lowering feeding expense, better feed performance, fish growth, water quality and eventually multiplying profit of fish and shrimp farmers. On average, the company's smart feeding product helps reduce the amount of feed used by around 21 percent. ${ }^{17}$

eFishery's product comprises hardware and software, including several sensors to monitor fish's movements and ripples in water in a pond. In this sense, it is a manufacturing company. If the sensors detect certain motions, the feeders can determine that fish are hungry and agitated, then dispense food appropriately. Farmers can watch the whole process in realtime on their smartphone and even schedule the system when they want to do so. The device also collects information on fish behaviors and farm production patterns, which eFishery wants to utilize to improve their products and create more solutions for the aquaculture industry.

It took eFishery several months to see its business to flourish. The company first won first place in two Indonesia startups competitions. With a price of US $\$ 975$ per piece, eFishery sold 140 units in only 7 months from February to September 2014 with total revenue of this year exceeded $\$ 100,000$ dollar. ${ }^{18}$ In 2015 , the company disclosed to have more than 17,000 fish and shrimp farms in its sales pipeline ${ }^{19}$. It claimed to be profitable in 2018 with 261 times revenue growth in the 2016-2018 period. These initial successes help the company to raise total funding of $\$ 5.2$ million dollars until now. ${ }^{20}$

\footnotetext{
15 Source: https://www.crunchbase.com/organization/deep-glint\#section-funding-rounds and https://pulsenews.co.kr/view.php? year $=2019 \&$ no $=151329$.

16 eFishery's website at https://efishery.com/en/home/; also https://www.techinasia.com/this-startup-is-building-

smartphone-powered-fishtech-for-indonesias-commercial-aqualife

17 https://www.techinasia.com/indonesia-startup-efishery-funding-news

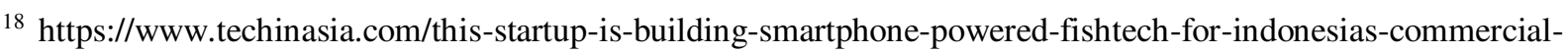
aqualife

19 https://www.techinasia.com/indonesia-startup-efishery-funding-news

20 https://www.techinasia.com/indonesian-aquaculture-startup-efishery-nets-4m-funding
} 
eFishery could have a massive impact on Indonesia aquaculture. The company's products can help enhance the lives of more than 3.3 million Indonesian fish farmers (FAO, 2018). With 3.3 million fishponds and 2.7 million fish farms, Indonesia aquaculture machinery is a million-dollar industry thus the huge impact of eFishery has not yet to come. The company's products are currently used in thousands of farms in 16 provinces and 67 cities/districts in Indonesia; from Maluku to North Sumatera. The company also received orders from Singapore, India, Thailand, China, Brazil, and some countries in Africa and is operating pilot projects in Bangladesh and Vietnam as well. The future of eFishery is to become a platform that connects the entire ecosystem in fish and shrimp farming, creating a more accountable and profitable industry across the region.

\section{Biofuels in Brazil ${ }^{21}$}

Brazil has been able to build an urban private transport system based largely on homegrown and processed ethanol and (now) biodiesel. Brazil developed its bioethanol program in the 1980s through utilizing its own domestic resources (sugar cane plantations fed by rainfall without the need for irrigation) and technology. Through the National Alcohol Program, dating back to the military dictatorship in the 1970s, a market for ethanol was mandated as a means of saving oil imports. Domestic producers were encouraged as well as local suppliers of equipment (such as Dedini) thus creating an entire value chain on the supply side. On the demand side there was initial resistance because cars had to be either ethanol-adapted or conventional, and consumers that switched to ethanol-only vehicles in the 1980s were then burned as the global price of oil fell and ethanol became non-competitive. But in the 2000s Brazil's ethanol program was revived with the strong support of the government, of the national oil company Petrobras, and with the demand-side innovation (developed in Brazil) of flex-fuel vehicles, which could run on ethanol, gasoline or any combination of the two.

The success of the Brazilian bioethanol program (now being replicated in the case of biodiesel) is not a conventional story of import of product, followed by import of equipment and insertion in global value chains in order to access technology. Rather, Brazil was already a sugar producer at the world frontier in terms of technology and world leader in terms of costs - and was able to carry these initial advantages across to the production of ethanol. Technology for ethanol production was initially imported and rapidly domesticated (leading to formation of domestic equipment suppliers such as Dedini) and then diffused rapidly through the R\&D efforts of the national R\&D institution, EMBRAPA. This was the body (equivalent to ITRI in Taiwan) that maintained a technological watch on global developments, and utilized advanced technological methods for researching Brazil's sources of comparative advantage, e.g. soils suitable for sugar cane cultivation as revealed by satellite surveillance. But these advantages inherent in Brazil's situation would have been reduced to naught had it not been for strong government support in mandating a steadily increasing market share for domestically produced ethanol, and the role of the national oil company Petrobras in acting as primary distributor of ethanol through pipelines and terminals and fuel outlets across the country. Now Brazil is building an entire value chain for production of first-generation ethanol as well as creating companies to usher in the second generation (in competition as well as collaboration with US

21 This case is originally from Lee and Mathews (2013; 2018). 
and European firms).

\section{Cases from Africa}

There do exist several cases of leapfrogging in Africa. ${ }^{22}$ A notable example of leapfrogging in Africa is the M-Pesa in Kenya, which serves as efficient and convenient mobile banking and payment systems for African people without access to offline banking. ${ }^{23}$ M-Pesa's founders were looking for a method to apply their mobile payment system to solve other problems. Thus, they started another company called M-Kopa Solar to provide solar energy to rural households in Africa. Their system uses three readily available technologies, namely, solar generation and low-energy LED lights, mobile payments similar to M-Pesa, and the SIM cards embedded in the M-Kopa control unit. M-Kopa's innovation is to package these technologies and combine them with a mobile payment system, thereby providing solar energy products at affordable prices. M-Kopa is an effective off-the-grid solar system for Africa, with poor landbased infrastructure and frequently erratic electricity supply. M-Kopa enabled children in rural area to study after school and relieved their mothers from the burden of fetching firewood and burning kerosene late into the night. Thus, the process is a leapfrogging out of kerosene-based lighting, bypassing the grid-based electricity into off-grid renewable energies. This system is an innovation not only in technological terms but also in terms of business models suited to African conditions.

An example from Africa is the use of solar power in desert grasslands in rural areas in Jigawa, Nigeria (Lee and Mathews 2013). This semi-desert area has no water supply. The traditional option was to open wells with ropes and buckets, hand pumps, or governmentsupplied diesel-powered pumps that worked until they broke down or until villagers ran out of money to buy the expensive diesel. This problem was solved through solar-powered pumps designed to run maintenance-free for at least 8 to 10 years.

Another example is the O\&L Group in Namibia (Lee et al. 2014). Established by Mr. Shilongo, this company started in retail and brewery and then diversified into dairy and solar energy. O\&L survived and expanded quickly with government support (against a South African company's effort to sabotage this company by price dumping) with sales reaching approximately 4 percent of the GDP of Namibia. O\&L plans to enter into the energy business, including wind power, because Namibia imports electricity from South Africa and Angola. However, the company must first solve the hurdle of a government-imposed grid monopoly.

\section{India: A Case of Country-Level Stage-skipping Leapfrogging ${ }^{24}$}

In the economics literature, a contrast has been made between China's manufacturingled growth and service-led growth. ${ }^{25}$ China's impressive catch-up since the 1980 s is deemed classical, as its catch-up growth has been accompanied by typical structural changes, with the

\footnotetext{
22. These cases are also presented in Chapter 7 of Lee (2019).

${ }^{23}$ This story of M-Pesa and M-Kopa relies on Shapshak (2016).

${ }^{24}$ This case of India is a summary based on Chapter 8 of Lee (2013).

${ }^{25}$ For instance, see Winters and Yusuf (2007).
} 
share of primary sector shrinking over time, whereas that of the secondary and tertiary sectors is increasing. India's case is unusual because the increase in the share of the service sector is matched closely by the decrease in agriculture, whereas the share of the secondary sector remains almost flat. ${ }^{26}$ Actually, India's service sector has grown steadily since the 1980s, with its GDP share exceeding 50\%. There is some view among economist that the growth of India's service sector might be another story of premature tertiarization typical in developing countries, in which generally low-paying service jobs are generated in the urban informal sector. Although this may be partly true in India, it is not representative of India's whole service sector. In particular, India's IT service industry has generated high-paying jobs and upgraded into higher value-added segments of the value chain.

Another impressive indicator of India's success is its rising share of service exports in relation to total exports. This share reached 35\% in the mid-2000s in India and now more than $50 \%$ in the 2010s, one of the highest in the world, surpassing even that in advanced economies. In contrast, the export share of service in China stayed at around $10 \%$ in the 2000s. Therefore, if India follows the proven success path of export-led growth, then it is likely to do so through service exports (tertiary) and not through manufacturing (secondary) or agriculture (primary) exports, as in other developing countries.

Growth in most of industrialized countries in the world has been fueled by manufacturing, with the service sector increasing only after this stage of manufacturing-based growth ends. Such pattern has been explained in terms of the income elasticity of service, or service as an intermediate input to manufacturing. However, in India, the service sector progressed even without going through the usual growth stage in the manufacturing sector (Ok et al 2014). Thus, we consider the case of India as leapfrogging in terms of industrial structure because the service sector developed first even before the manufacturing sector grew to take some share in the economy. Now under the Modi's leadership, India is trying to promote manufacturing too. In this sense, it is a detour via leapfrogging; India bypassed the stage of manufacturing-led growth but leapfrogged into the service-led growth and then back to promote manufacturing.

It is to be noted that this service-led growth has been led by the three giants, such as, Infosys, Tata Consultancy Services (TCS), and Wipro, and that these Indian firms have undergone the three stages of upgrading: body shopping, offshoring, and global delivery model (GDM), which are similar to the manufacturing stages of OEM, ODM and OBM, respectively (Lee et al 2014). Among these three, the case of Wipro is a perfect fit in this story of leapfrogging. This company was established as an agro-business company that produced and sold vegetable oil products (Hamm 2007). However, with its entry into the personal computer era, Wipro engaged in the business of assembling and selling personal computers as well. Shortly thereafter, the firm realized its weak competitiveness against foreign products and thus switched to PC maintenance and repair service. The Y2K panic near to year 2000 brought a decisive boost to Wipro's business, turning the firm into a global IT service company listed in the New York Stock Exchange. Wipro's historical evolution illustrates a company's leapfrogging into IT service, bypassing the stage of IT manufacturing.

\footnotetext{
${ }^{26}$ According to the figure 8-1 of Lee (2013), in China, the manufacturing sector's contribution to the total GDP has steadily increased, reaching $30 \%$ by the 2000s and accounting for the sharp decrease in agriculture's contribution to GDP. By contrast, the GDP of India's manufacturing sector has never exceeded $20 \%$, with its size remaining constant at around $15 \%$ for over two decades.
} 


\section{Enabling Policies and Prospect for Leapfrogging}

\subsection{Enabling Conditions and Policies}

The enabling conditions and policies for leapfrogging can be discussed in terms of the NIS (national innovation systems). Specifically, implementation of leapfrogging strategy should first start from considering the one-pre-condition and two risks of leapfrogging discussed in the section 4. In other words, the first thing for a latecomer economy to do is to build up a certain level of capabilities in production technologies, if not innovation capabilities. As discussed in section 4, Korean case of leapfrogging into digital TV ahead of Japan was possible because Korean companies had the experience of making analog TV.

The need for building certain level of technological capabilities does not necessarily mean isolated style of indigenous R\&D effort. If it is going to lead to leapfrogging, local R\&D effort should go together with getting access to the global knowledge base, without which leapfrogging catch-up is almost impossible as the late-comer firms cannot generate radically new technologies themselves. Although we are trying leapfrogging, the products from leapfrogging are often a combination of the latecomer production capability with the seed technology from the forerunning firms. Although what the late-comer firms developed is a new product, it was possible by applying the foreign sourced sciences and the seed technology to the specific development target.

Thus, possibility of leapfrogging also calls for a need to modify the theories of technological development (Lee et al 2015). According to the stage theories of technological development, the latecomer country moves from 'internalization stage' to 'generation stage' to produce 'new knowledge' to the world. Now, this sequential mode of learning has to be modified, specifically in terms of the change in the channels for knowledge access. While in the past or in the path-following catch-up, the main channels have been licensing or FDI, the current cases of a path-creating or leading catch-up during the paradigm shift period show the importance of new channels such as co-development with, and acquisition of, foreign firms or university startups as well as collaboration based on complementary assets owned by late-comer firms. Horizontal collaboration with universities, public research organization, or forerunning firms is possible only when the late-comer firms have something to give in return. While absorption capacity was emphasized in the old story of technology transfer via license or FDI, now complementary assets, which have been created with speedy R\&D activities and investment in production, seems to be important in these new ways of accessing knowledge.

The next important thing is to manage the risks involved in leapfrogging. The primary risk with leapfrogging has to do with how to make a right choice among the several alternative technologies. In this regard, cooperation with public R\&D organs, universities, and other entities is critical as such $R \& D$ consortium can reduce the involved risk by pooling knowledge together. These collaborating entities may contribute critically by conducting "technology watch" to interpret and monitor the state-of-the art trend of R\&D activities in foreign countries (Lee et al 2015). For example, in the case of Korean leapfrogging into mobile phones or digital TV, it was the ETRI (a government research institute) which identified the small firm like Qualcomm as the R\&D partner to develop digital cellular phone systems, and the KITECH and ETRI that carried out R\&D activities and coordinated the consortium of research projects in in digital TV. 
Despite the possibility of mitigating the risk of making right or wrong choice among emerging technologies, the issue of whether sensible targeting is possible has always been a controversial issue. But, in such debate against targeting, design failure is often mixed up with targeting failure (Lee 2017). An example is the case in South Africa, where they developed their own electric cars called 'Joule'. Swart (2015) explained that the South African government provided the initial funding and established a state-owned startup called Optimal Energy in 2005. The company initially succeeded and had four roadworthy prototypes by December 2010. However, the company closed in June 2012 despite the technical success. The government, who was the major shareholder, decided to stop the funding required to start large-scale production of the electric cars because of uncertainties in marketing success. The failure of 'Joule' cars was caused by the lack of involvement of private companies to take the role in volume production and sales. Thus, existing foreign multi-national companies and local auto companies did not want this new 'disruptive innovator', a state-owned company, to grow as another rival that sells cars. The government should have formed a public-private consortium with the plan that volume production would be carried out by private actors after the consortium developed the prototype (Lee 2017).

Thus, this South African case can be considered one of 'design failure' rather than a 'targeting failure' (Lee 2017). The reason that the process should involve private firms in terms of design is twofold: they know where market demand is, and they eventually run the show. Caution against government activism often does not distinguish whether the sources of failure are due to targeting or design. The sources are often mixed together. While one might expect more cases of targeting failure, this is not always the case. Uncertainty diminishes if targeting is seen in terms of identifying the potential or existing markets as long as the private sector with knowledge about the markets are involved. If not on the frontier, the targets may be obvious because there often exists a clear benchmark case, and then you may attempt to identify niches between existing firms and projects. Numerous public initiatives fail because of design or capability failure, where the latter means low execution capabilities.

While the above discussion is about avoiding design failure, targeting failure does exist. One way to minimize the possibility of target failure is to utilize the idea of entrepreneurial discovery (ED) suggested by the smart specialization framework (Foray 2015). The process would be as follows (Lee 2017). First, policy makers should organize a public-private joint taskforce, which includes representatives from the private sector, and administer a survey to existing private firms and entrepreneurs on the nature of business items or technological areas where they see near-future potential, opportunities, risks, and bottlenecks when entering or starting out in these future areas. The business areas to be identified by surveys are those areas where the private sector see certain market potentials often associated with emerging technologies but with some technological, financial, and other related environmental (regulation) uncertainties. Private firms may know better where the next markets are, but cannot be sure whether they will be able to develop the necessary and right technologies and whether they will be able to raise the funds for such $R \& D$ and initial marketing. In other words, new business/technology areas with more certain market potential but uncertain technological, financial, and regulatory uncertainty will be targetable areas. Policy intervention promotes these identified areas by mobilizing public and private resources and competencies that correct market and coordination failures. 


\subsection{Prospect of Leapfrogging-based Development}

The answer to the question of whether the 4IR can be either a new window of opportunity for leapfrogging or sources for further risk for the latecomers is that it depends on each country's responses and readiness, including industrial policy, digital literacy, skill and educational level compared to wage rates, and domestic market size and position in GVC (Lee et al 2019). We can conceive of the following three groups of countries (Table 2).

\section{[INSERT TABLE 2 HERE]}

The first group of countries may correspond to a most promising scenario consistent with a proper leapfrogging from industry 2.0 (mass production) to industry 4.0 (smart factory) bypassing the intermediate stage of industry 3.0 (automation). This seems to be possible or happening in an economy with certain level of indigenous manufacturing basis, like China, South Korea or Brazil, supported by the commitment from the government and consensus at the society level. Smart Factory paradigm has also risen also a solution to maintain competitiveness by overcoming the issue of the increasing wage rates or labor shortage in several economies, which is basically similar to the underlying motivation for Germany to initiate Industry 4.0. A mode of implementing this initiative toward smart factory (or automation) can take the form of public-private partnership or collaboration, in conjunction with active industrial policy. Of course, the possible risk in the regards is the wastes of public resources or budget in case of failures with such initiatives.

The second group of economies are those with FDI-based manufacturing, like those in Southeast Asia or Latin America, where leapfrogging is up to the choice of parent MNCs. In these economies, MNCs faces diverse alternatives, such as relocation to other economies looking for cheaper wages and reshoring back to home countries. In this regards, some promising stories of from the FDI-based electronics sector in Penang, Malaysia and auto sector in Thailand about some automation and upgrading into higher end segments indicate that the key factor for success is the local institutions which has enabled training and upskilling of local force, and thereby held MNCs to remain in the localities (Lee et al 2020).

The last group may include other latecomer economies where more promising areas and stories related to the 4IR seem to be happening in service sectors or servicitized-manufacturing sectors. Possible example countries may include Indonesia, Philippines, Argentina and many countries in Africa. For instance, there is recently some boom of startups in Southeast Asia but successful cases tend to be all in services, like mobility, ecommerce, games, mobile payments, travel, music and entertainments, and other apps-based services. ${ }^{27}$ Some of these, like Grabs are very successful and large-scale and even thus competing with global giants like Uber, and are creating many jobs locally. Most importantly, they should have spillover effects on related manufacturing too; for instance, GO-JEK is Indonesia's first unicorn which started as a motorbike and taxi-hailing app and then expanded to food delivery, groceries, massages, and mobile payments.

${ }^{27}$ See the list of top 15 startups in Southeast Asia at the https://www.techinasia.com/15-mostwellfunded-startups-southeast-asia. 
It is quite plausible that success in services may have boosting effect on local manufacturing, given the emerging trend of blurring of boundary between service and manufacturing. The cases of companies like eFishery and DeepGlint introduced in section 6 can be considered an example companies sitting border line between manufacturing and solution providers; eFishery provides an Internet of Things (IoT) solutions for efficient feeding of fishes and produces hardwares for fish and shrimp farming businesses. DeepGlint produces a security camera and provide a face-recognition system based on big data.

Of course, the possible risk facing these kinds of local startups would be the entry and competition from big businesses from abroad. Thus, these startups are advised to seek niches unless there is market protection by the government against foreign firms; it is well-known that many of IT startups and later giants in China (eg, Baidu, Alibaba and Tencent) were able to grow owing to asymmetric regulations against foreign firms, like Google, Amazon, Uber, and Facebooks.

The case of Indian leapfrogging into IT service followed by recent promotion of manufacturing discussed in the preceding section indicate the possibility of the idea of the service-first leading to manufacturing later as a development strategy. Service sector in India has risen as a viable export sector accounting more than half of total exports, the highest ratio in the world. The earnings in convertible currency generated by such exports has become a basis for Indian promotion of manufacturing which requires imports of capital goods by dollars. We do not have to discount this already-occurring phenomenon by labeling as premature deindustrialization. Some latecomer economies might have to go along this road of economic growth, given the high entry barrier in manufacturing compared to services.

One insight from emerging promising cases in these latecomer economies would be that latecomers do not have to be original inventors of new innovations but often suffices to be follow-on innovators or even fast-adopters with local twists, which have been classified as one variation of leapfrogging in section 2 above. Leapfrogging is possible not only by hard technological innovations but also by business model innovations adopting technological innovation abroad. This has important implications for more laggard economies, like those in Africa. The cases of leapfrogging in Africa discussed in the preceding section tend to be like adoption of new technologies than local innovations. However, adoption is a beginning or stepping stone for learning and eventual innovation. Learning is not possible without adoption. Manufacturing firms in East Asia, such as Samsung and Hyundai Motors in Korea, all started from the adoption of foreign technology for production, learning from using, enhancing productivity by mastering production technologies, and finally acquiring design technology (Lee 2005; 2013a). Recent examples can be found in the renewable energy markets of China, Brazil, and India, which involve the transition toward low-carbon economies. Options for LDCs in low-carbon technologies include wind, solar, biogas, and geothermal energy sources. In this case, coordinated initiatives and incentives for early adopters are essential in reducing the risks associated with weak initial markets.

While the discussion above centered upon the different types of economies facing the different initial conditions, policy suggestions involving leapfrogging can also be made in terms of different types of firms with different level of initial capabilities. Here we may divide firms in an economy into incumbents and startups, and the former can further include three types like 
leader, followers, laggards in terms of their level of capabilities. Then, we can discuss the issue of which types of leapfrogging or other alternative might be suitable for which types of firms.

Relatively speaking, one can argue that path-creating type leapfrogging would be more likely to happen to startup because they are the ones which has made least amount of investment into the existing or old modes of technologies or business models. In other words, diverse technologies associated with the 4IR can be a source for product (or business model) innovations than for process innovation which is more relevant for incumbents. Of course, even the product innovation does not have to be really new or radical but follow-on innovation or adopt-then-improve type innovation.

Next, leader or follower type firms in emerging economies tend to have some experiences and absorptive capacity and thus are likely to be in a position to try stage-skipping leapfrogging. Given their accumulated know-how and production experience, they can be considered to satisfy the pre-conditions for such leapfrogging but they should be aware of the two risks involved in leapfrogging discussed in the preceding section (4.2). Given that they are incumbents, their leapfrogging is likely to be not inter-sectoral but intra-sectoral leapfrogging over different generations of technologies; for instance, from mass-production to smart factory bypassing the stage of traditional automation; or from lean production to smart production bypassing the stage of integration production. Also, the nature of innovation would be more process innovation than product innovation.

Last, laggard firms are advised not to try pre-mature leapfrogging but build first absorptive capacity and technological capabilities in their niche areas and thereby to try to upgrade by moving into higher ends segment of GVC. In other words, they need to go through the stage of 'several detours' (Lee 2019) which is a pre-condition for trying leapfrogging. Some of the detours include the detour from imitation to innovation by providing somewhat weak IPR protection to promote imitative R\&D and diffusion of innovations, as well as from building certain degree of domestic value chains while participating at the GVC (Lee 2019).

Also, supportive policies can also be different across firm types. For instance, for startups venture capital (VC) funding including public-private joint $\mathrm{VC}$, may be more relevant, whereas, whereas for incumbents more relevant modes of financing would be conventional loans from commercial banks or subsidized loans from public sector, as well as conventional financing from equity markets.

In general, new innovations in the 4IR and sustainable development seems to require new forms of public policy and public-private partnerships. Its comprehensiveness and across-board nature require policy response not by one specific gov't ministry but consultation and responses by multi-ministries with the coordination by the prime minister's office. Also, the responses should be timely because some negative impacts of 4IR could happen earlier than expected, such as losses of some assembly jobs and BPO jobs. Also, the 4IR would also disrupt and reshape the current GVC, and then new forms of insertion into the new GVC could be not necessarily at the level of firms but at the level of individuals. In this light, education and training would take a decisive role, and it would be desirable to integrate labor market at the regional level and to promote start up by young entrepreneurs by spreading the successful role models and cases. 


\section{REFERENCES}

Arrow, K. J. (1962). The Economic Implications of Learning by Doing. Review of Economic Studies, 29(3): 155-173.

Abernathy, W. J., and J. M. Utterback. (1978). Patterns of Industrial Innovation. Technology review, 80(7): 40-47.

Baldwin, R. E. 2016. The Great Convergence: IT and the new globalization, The Belknap and Harvard UP.

Bell, M. and Pavitt, K. (1995). The Development of Technological Capabilities, in Haque, I. (ed.), Trade, Technology and International Competitiveness. Washington D.C.: The World Bank.

Christensen, C. M. (1997). The Innovator's Dilemma: When New Technologies Cause Great Firms to Fail. Boston, Mass: Harvard Business School Press.

D'Costa, A. P. (1999). The Global Restructuring of the Steel Industry: Innovatons, Institutions, and Industrial Change. London; New York: Routledge.

FAO. 2018. The State of World Fisheries and Aquaculture.

Freeman, C. (1987). Technology Policy and Economic Performance: Lessons from Japan. New York: Pinter.

Freeman, C. and L. Soete. (1997). Development and the diffusion of technology in Freeman, C. and L. Soete (eds.), The Economics of Industrial Innovation, Pinter Publishers, London.

Foray, Dominique (2015). Smart Specialization, London: Routledge

Foster, R. (1986). Innovation: The Attackers Advantage Macmillan. London: Pan Books.

Gerschenkron, A. (1962). Economic Backwardness in Historical Perspective. Harvard University Press, Cambridge,Mass.

. (1963). The early phases of industrialization in Russia: afterthoughts and

counterthoughts in W. W. Rostow.(ed.), The Economics of Take-off into Sustained Growth, Macmillan, London.

Giachetti, C., and G. Marchi. (2017). Successive Changes in Leadership in the Worldwide Mobile Phone Industry. Research Policy, 46(2): 352-364.

Hamm, S. (2007). Bangalore: How Indian tech upstart Wipro is rewriting the rules of global competition. New Delhi: Tata McGraw-Hill.

Hidalgo, C. A., B. Klinger, A.-L. Barabási, and R. Hausmann. (2007). The Product Space Conditions the Development of Nations. Science, 317(5837): 482-487.

Hobday, M. (1995). Innovation in East Asia: The Challenge to Japan. Edward Elgar, Hants 
ILO (International Labor Organization: J. Chang, R. Gary, \& P. Huynh). (2016a). ASEAN in Transformation: How Technology is changing Jobs and Enterprises. Geneva: ILO.

. (2016b). ASEAN in Transformation: The future of Jobs at Risk of Automation.

Geneva: ILO.

Ivus, O. (2010). Do Stronger Patent Rights Raise High-Tech Exports to the Developing World? Journal of International Economics, 81(1): 38-47.

Joo, S. H., C. Oh, and K. Lee. (2016). Catch-up Strategy of an Emerging Firm in an Emerging Country: Huawei Vs. Ericsson. International Journal of Technology Management, 72(1-3): 19-42.

Kim, L. (1980). Stages of Development of Industrial Technology in a Developing Country: A Model. Research Policy, 9(3): 254-277.

Kim, Y.-Z., and K. Lee. (2009). Making a Technological Catch-Up in the Capital Goods Industry: Barriers and Opportunities in the Korean Case. In Malerba, F. (Ed.), Sectoral Systems of Innovation and Production in Developing Countries, pp. 259-286.

Cheltenham, UK: Edward Elgar Publishing.

Lall, S. (2000). "The Technological Structure and Performance of Developing Country Manufactured Exports, 1985-98." Oxford Development Studies, 28(3): 337-369.

Lee, Keun. (2019). The Art of Economic Catch-up: Barriers, Detours and Leapfrogging in Innovation Systems. Cambridge Univ. Press.

Lee, Keun. (2017). "Smart Specialization with Short-Cycle Technologies and Implementation Strategies to Avoid Target and Design Failures." in Radosevic, S., et al. (Eds), Advances in the Theory and Practice of Smart Specialization, pp. 201-224. London: Academic Press.

. (2013). Schumpeterian Analysis of Economic Catch-up: Knowledge, Path-creation, and the Middle-income Trap. Cambridge Univ. Press.

(2005), Making a technological catch-up: barriers and opportunities, Asian Journal of Technology Innovation 13(2), 97-131.

Lee, K., and Ki, J.-h. (2017). Rise of latecomers and catch-up cycles in the world steel industry. Research Policy 46(2): 365-375.

Lee, K., C. Juma, and J. Mathews. (2014). Innovation Capabilities for Sustainable Development in Africa. in Monga, C. 1. and J. Y. Lin (Eds), Handbook of Africa and Economics. Oxford: Oxford University Press.

Lee, K., and C. Lim. (2001). Technological Regimes, Catching-up and Leapfrogging: Findings from the Korean Industries. Research Policy, 30(3): 459-483.

Lee, K., and F. Malerba. (2017). Catch-up cycles and changes in industrial leadership: Windows of opportunity and responses of firms and countries in the evolution of sectoral systems. In: Research Policy 46: 338-351. 
Lee, K., and J. Mathews. (2018). How Emerging Economies Can Take Advantage of the Fourth Industrial Revolution. Agenda Weekly: Expert Edition. Geneva: World Economic Forum. Accessed at https://www.weforum.org/agenda/2018/01/.

. (2013). STI for Sustainable Development. UN: Committee for Development Policy, Background Paper, No. 16.

Lee, K., and Kim, Y.K., 2010. IPR and technological catch-up in Korea. In: Odagiri, H., Goto, A., Sunami, A., Nelson, R. (Eds.), Intellectual Property Rights, Development and Catch-up. Oxford University Press, London

Lee, K., and SS. Ramanayake. (2018). Adding-up problem and wage-productivity gap in exports of developing countries: A source of the middle-income trap. The European Journal of Development Research, 30(5): 769-788

Lee, K., C. Lim, and W. Song. (2005). Emerging Digital Technology as a Window of Opportunity and Technological Leapfrogging. International Journal of Technology Management, 29(1-2): 40-63.

Lee, K., Chan-Yuan Wong, Patarapong Intarakumnerd and Chaiyatorn Limapornvanich. (2020). Is the Fourth Industrial Revolution a window of opportunity for upgrading or reinforcing the middle-income trap?, Journal of Economic Policy

Reform, DOI: 10.1080/17487870.2019.1565411

Lee, K., M. Szapiro, and Z. Mao. (2018). From Global Value Chains (GVC) to Innovation Systems for Local Value Chains and Knowledge Creation. European Journal of Development Research, 30(3): 424-441

Lin, J. (2012). New Structural Economics: A Framework for Rethinking Development and Policy. Washington: World Bank

Lundvall, Bengt-Åke. (1992). National systems of innovation: Toward a theory of innovation and interactive learning. London: Frances Pinter.

Malerba, F. (2005). Sectoral Systems of Innovation: A Framework for Linking Innovation to the Knowledge Base, Structure and Dynamics of Sectors. Economics of innovation and New Technology, 14(1-2): 63-82.

(2004). Sectoral Systems of Innovation: Concepts, Issues and Analyses of Six Major Sectors in Europe. Cambridge: Cambridge University Press. 264. (2002). Sectoral Systems of Innovation and Production. Research Policy, 31(2): $247-$

Mathews, J. A. (2005). Strategy and the Crystal Cycle. California Management Review, 47(2), 6-32

$\mathrm{Mu}$, Q., and K. Lee. (2005). Knowledge Diffusion, Market Segmentation and Technological Catch-Up: The Case of the Telecommunication Industry in China. Research Policy, 34(6): 759-783.

Nakamura, T., and H. Ohashi. (2012). Effects of Re-Invention on Industry Growth and 
Productivity: Evidence from Steel Refining Technology in Japan, 1957-1968. Economics of innovation and New Technology, 21(4): 411-426.

Nelson, R. R. (1993). National Innovation Systems: A Comparative Analysis. New York: Oxford University Press.

Perez, C., Soete, L. (1988). Catching-up in technology: entry barriers and windows of opportunity, in: Dosi, G., Freeman, C., Nelson, R., Silverberg, G., Soete, L. (Eds.), Technical Change and Economic Theory. Pinter Publishers, London, pp. 458-479.

Rogers, E. M. (2003). Diffusion of Innovations (5th Ed). New York: Free Press.

Schwab, Klaus. (2016). The Forth Industrial Revolution. World Econ Forum. Geneva.

Shapshak, T. (2016). How Kenya's M-Kopa Brings Prepaid Solar Power to Rural Africa. Forbes magazine. available at:

https://www.forbes.com/sites/tobyshapshak/2016/01/28/how-kenyas-m-kopa-bringsprepaid-solar-power-to-rural-africa/\#79415e822dbf.

Shin, J.-S. (2017). Dynamic Catch-up Strategy, Capability Expansion and Changing Windows of Opportunity in the Memory Industry. Research Policy, 46(2): 404-416.

Shin, W., Lee, K., \& Park, W. G. (2016). When an Importer's Protection of IPR Interacts with an Exporter's Level of Technology: Comparing the Impacts on the Exports of the North and South. The World Economy, 39(6): 772-802

Spence, M. (2011). The Next Convergence: The Future of Economic Growth in a Multispeed World. New York: Farrar, Straus and Giroux.

Swart, G. (2015). Innovation Lessons Learned from the Joule EV Development. IAMOT 2015 Conference Proceedings.

Winters, L. Alan, and Shahid Yusuf. (2007). Dancing with giants: China, India, and the global economy. Washington DC: World Bank.

World Bank. (2010). Exploring the Middle-Income-Trap, East Asia Pacific Economic Update: Robust Recovery, Rising Risks, vol. 2. Washington, DC: World Bank.

Vernon, R. (1966). International Investment and International Trade in the Product Cycle. Quarterly Journal of Economics, 80(2): 190-207.

Westphal, L.E., L. Kim, and C.J. Dahlman. (1985). Reflections on the Republic of Korea's Acquisition of Technological Capability. in N. Rosenberg and C. Frischtak (eds).

International Technology Transfer, Praeger Press, New York, pp. 167-221

Yonekura, S. (1994). The Japanese Iron and Steel Industry, 1850-1990: Continuity and Discontinuity. New York: St. Martin's Press.

Zhou, Y., Tong, Y., Liu, X. and Qiu, S. (2012). Diffusion of solar thermal in China's BoP market, Proceedings of PICMET conference 2012. 


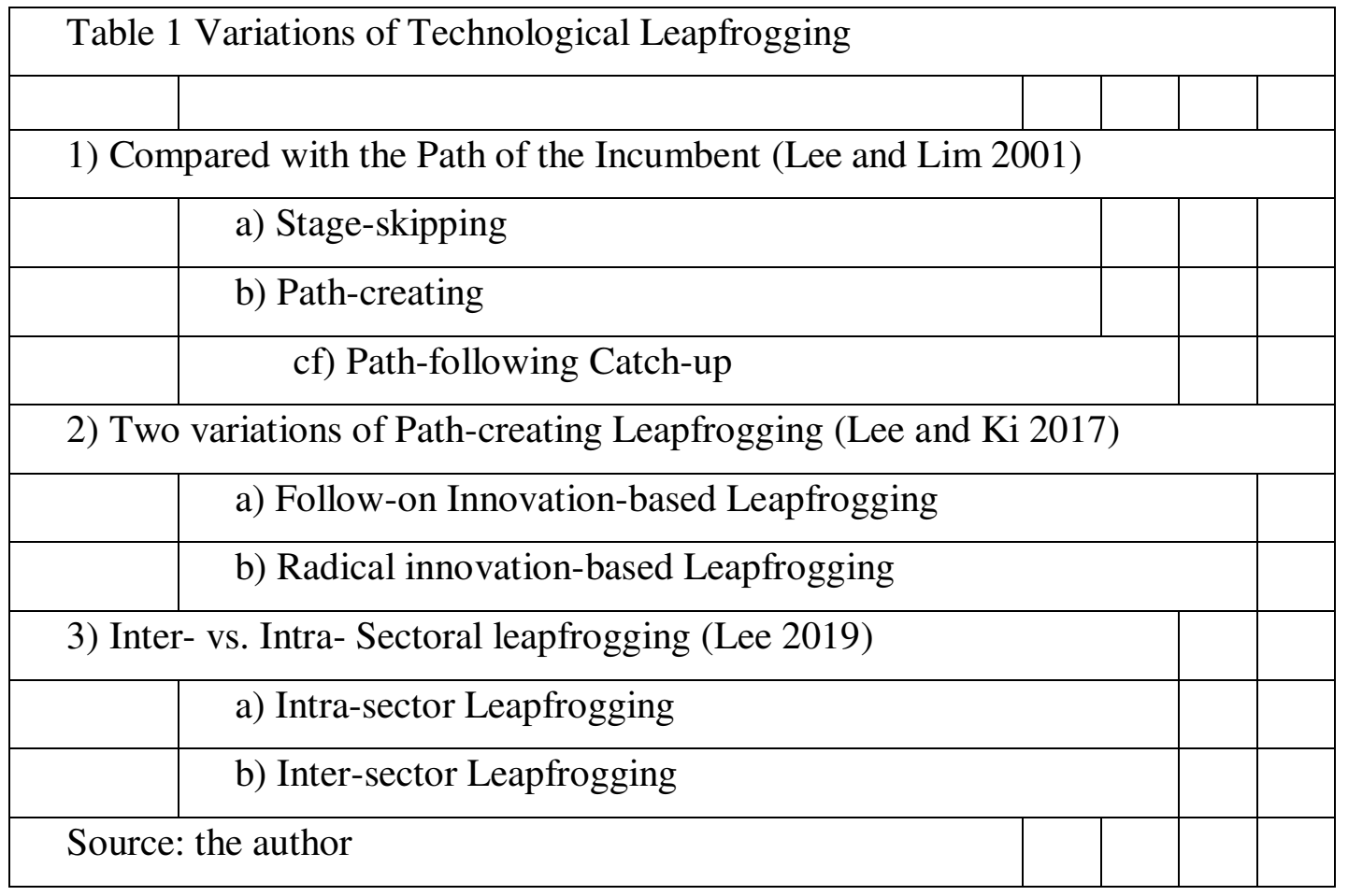


Table 1. Possible responses to the 4IR by country group

\begin{tabular}{|l|l|l|l|}
\hline & Group A & Group B & Group C \\
\hline $\begin{array}{l}\text { Main } \\
\text { feature }\end{array}$ & $\begin{array}{l}\text { National } \\
\text { manufacturing base }\end{array}$ & $\begin{array}{l}\text { FDI-based } \\
\text { manufacturing }\end{array}$ & $\begin{array}{l}\text { Weak } \\
\text { manufacturing base }\end{array}$ \\
\hline Examples & $\begin{array}{l}\text { China, Rep. of Korea, } \\
\text { Brazil }\end{array}$ & $\begin{array}{l}\text { Malaysia, } \\
\text { Thailand } \\
\text { Brazil, Mexico }\end{array}$ & $\begin{array}{l}\text { Indonesia, India, Philippines } \\
\text { Africa, Argentina }\end{array}$ \\
\hline $\begin{array}{l}\text { Promising } \\
\text { responses }\end{array}$ & $\begin{array}{l}\text { Leapfrogging into } \\
\text { smart factory }\end{array}$ & $\begin{array}{l}\text { Automation and } \\
\text { upgrading }\end{array}$ & $\begin{array}{l}\text { 4IR-related } \\
\text { service start-ups }\end{array}$ \\
\hline $\begin{array}{l}\text { Main } \\
\text { initiator }\end{array}$ & $\begin{array}{l}\text { Public-private } \\
\text { partnership }\end{array}$ & MNC decision & $\begin{array}{l}\text { Local entrepreneurs } \\
\text { introducing business model } \\
\text { innovations }\end{array}$ \\
\hline $\begin{array}{l}\text { Key } \\
\text { enabling } \\
\text { factors }\end{array}$ & $\begin{array}{l}\text { Industrial } \\
\text { providing funds and } \\
\text { technologies }\end{array}$ & $\begin{array}{l}\text { Local existence of } \\
\text { skills and training } \\
\text { institutions }\end{array}$ & $\begin{array}{l}\text { Initial financing; } \\
\text { venture capital }\end{array}$ \\
\hline Risks & Waste of public funds & $\begin{array}{l}\text { Relocation to } \\
\text { cheaper wage sites }\end{array}$ & $\begin{array}{l}\text { Entry by, \& competition with } \\
\text { large foreign businesses }\end{array}$ \\
\hline \multicolumn{2}{|c|}{ Source: the author } & \multicolumn{2}{|l}{} \\
\hline
\end{tabular}


Figure 1. Leapfrogging and Path-following Strategies of Latecomer Firms

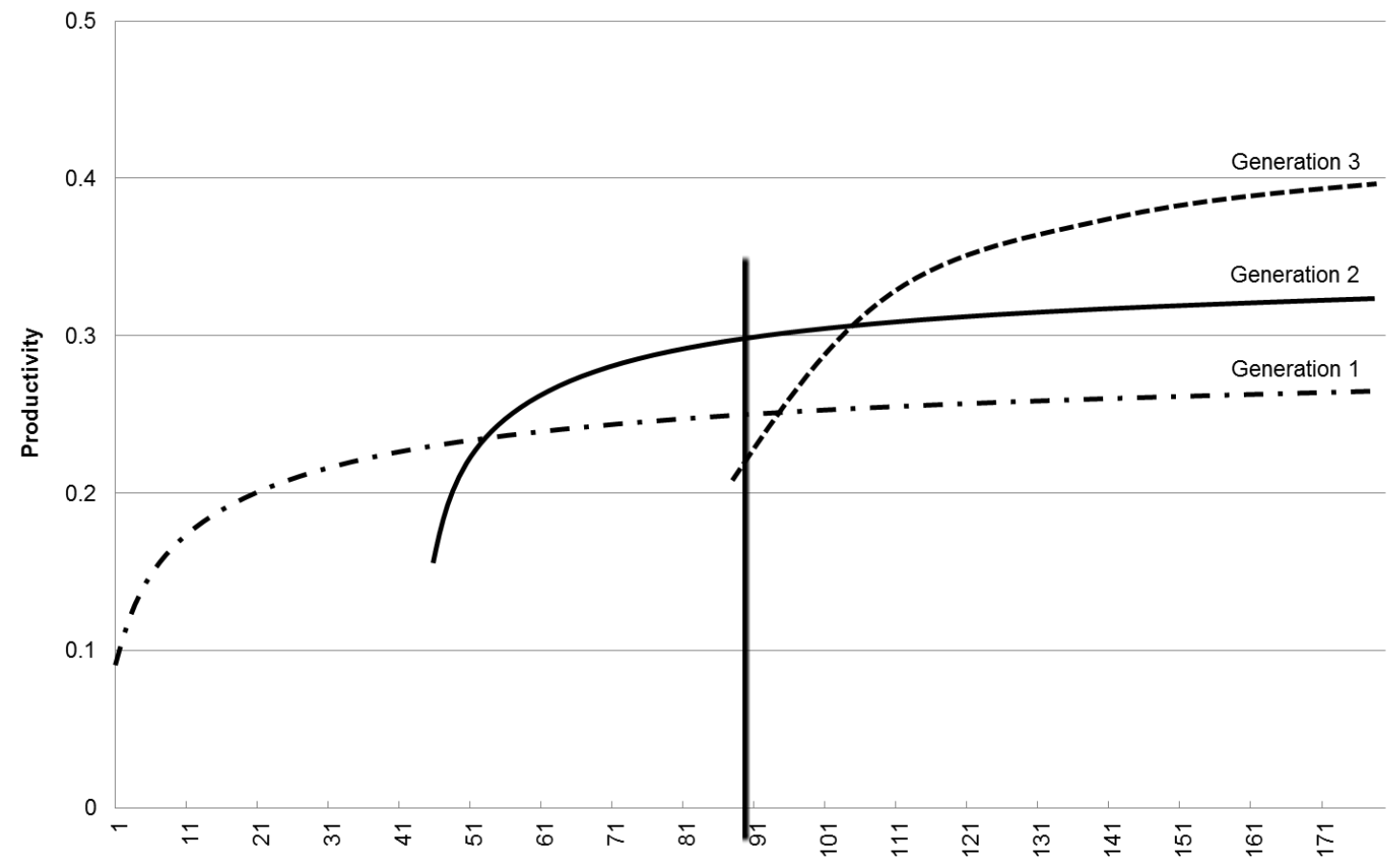

Source: Lee (2019: figure 5-1) which is from Lee and Ki (2017), adapted from Lee et al. (2016)

Notes: Path-following strategy $=$ To adopt the oldest (generation 1) technology

Stage-skipping strategy (leapfrogging I) = To adopt the latest (generation 2) technology

Path creation (leapfrogging II) strategy = To adopt emerging (generation 3) technology. 
Figure 2: Leapfrogging and the Environmental Kuznets Curve

(Redrawn by the author following the graph in Jackson and Roberts, 2000: copied from Figure 7-1 of Lee 2019).

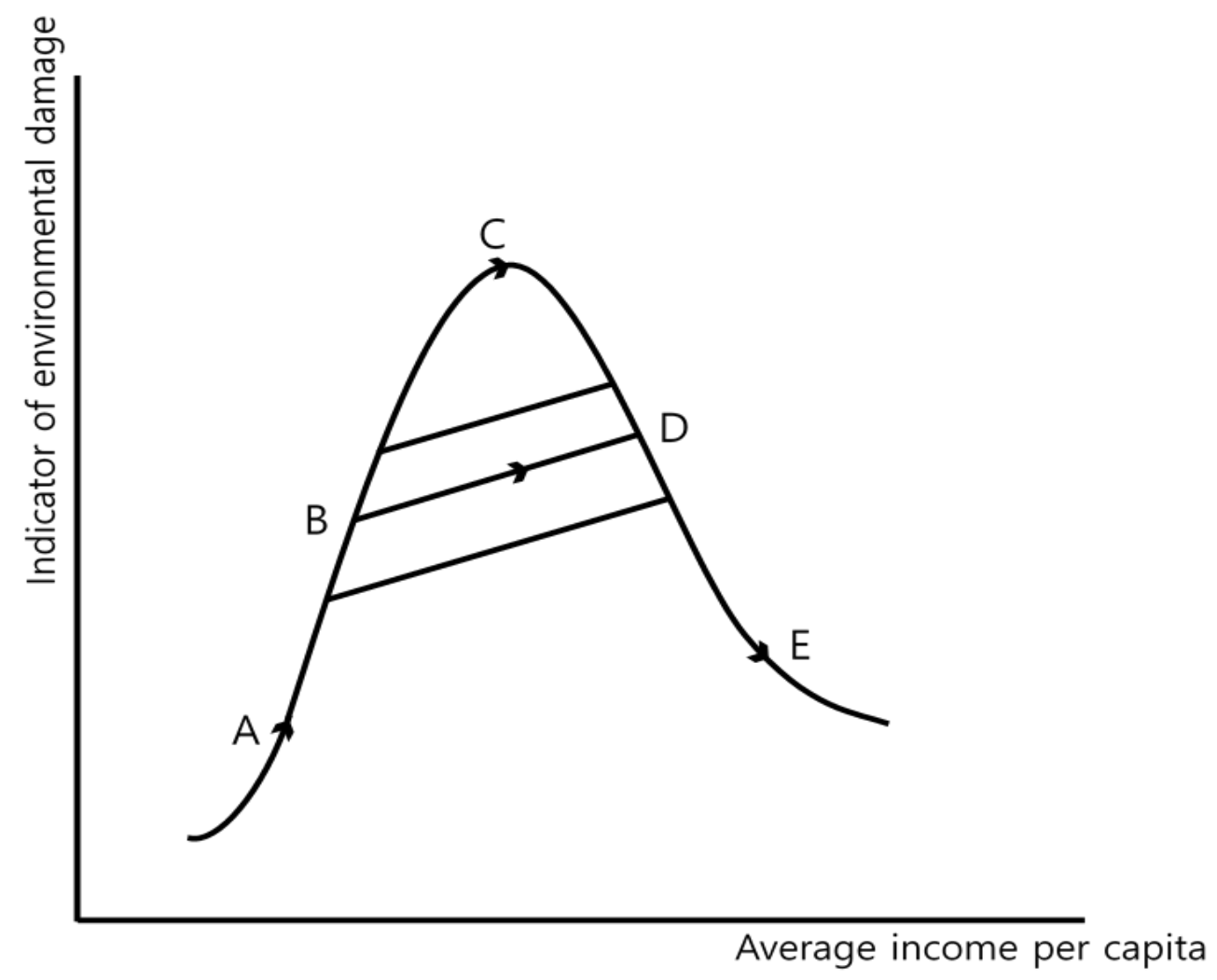

